Saudi Journal of Humanities and Social Sciences

Abbreviated Key Title: Saudi J Humanities Soc Sci

ISSN 2415-6256 (Print) | ISSN 2415-6248 (Online)

Scholars Middle East Publishers, Dubai, United Arab Emirates

Journal homepage: https://saudijournals.com

Original Research Article

\title{
Management of Child-Friendly School (SRA) In the Perspective of Islamic Education: A Study at Madrasah Ibtidaiyyah an Nizhamiyah and Madrasah Tsanawiyah Depok City
}

Siti Chadijah*, Armai Arief, Khairul Umam Noer

Muhammadiyah University, Jakarta, Indonesia

DOI: 1 10.36348/sjhss.2021.v06i01.001 $\quad$ |Received: 13.12 .2020 | Accepted: 31.12 .2020 | Published: 05.01 .2021

*Corresponding author: Siti Chadijah

\section{Abstract}

This study aims to find out the concept of Child-Friendly Schools (SRA) in the perspective of Islamic education. This research uses qualitative descriptive method with case study design in Madrasah Ibtidaiyyah An-Nizhomiyah and Madrasah Tsanawiyah Depok City. Data collection is obtained from the results of several relevant review literature, interviews, documentation and observations. Data is analyzed using data reduction, followed by presentation and drawing conclusions. The results of this study stated that the child-friendly school education system implemented in madrasah Ibtidaiyyah An-Nizhomiyah and Madrasah Tsanawiyah Depok city is in accordance with the concept of Islamic education. With the implementation of Child-Friendly School (SRA) in madrasahs make madrasah ibtidaiyyah An Nizhamiyah and Madrasah Tsnawiyah depok city become excellent madrasahs because Child-Friendly Schools are not only in accordance with the concept of Islamic education but also the management in the implementation of ChildFriendly Schools ranging from planning, organizing, implementing to evaluating make certain added values in realizing child-friendly education.

Keywords: Child-Friendly Schools, Islamic Education.

Copyright () 2021 The Author(s): This is an open-access article distributed under the terms of the Creative Commons Attribution 4.0 International License (CC BY-NC 4.0) which permits unrestricted use, distribution, and reproduction in any medium for non-commercial use provided the original author and source are credited.

\section{INTRODUCTION}

Education is one of the determinants of the nation's generation. Education and child protection are the first steps that can shape a human lifestyle. Recently, there have been many cases of violence occurring in the educational environment. The Indonesian Child Protection Commission reported that over a period of 9 years, from 2011 to 2019, there were 37,381 complaints of violence against children. Bullying cases recorded 2,473 reports, and this will still continue to increase. "The data of child complaints to the Indonesian Child Protection Commission is like an iceberg phenomenon. In the President's statement through the Online Information System Data Protection of Women and Children, from January to February almost every day there is news of the phenomenon of violence against children. "This will be the Government's attention to reduce the number of violence against children" he said.

Of the data on violence against children is none other than the lack of protection of children, both from the people around who are responsible, and the government as policy makers. The child is not given the right that should belong to him. The child protection system in Indonesia has been created in order to realize the rights that every child should have. The implementation of policies and laws in force needs to be continuously improved to overcome the occurrence of violence, mistreatment, exploitation and neglect of children.

The issuance of Regulation of the Minister of Women Empowerment and Child Protection No. 11 of 2011 on The Development of Child-Friendly City Policy is one form to guarantee all children's rights in each region, both district and city. Child-Friendly City (KLA) is an effort to align the government's commitment with existing resources as a whole and sustainable. Each district /city needs to consider the issue of children's rights in the preparation of regional development planning and protect children in the world of education. This is in line with Law No.23 of 2002 article 54 on Child Protection which reads, "Children in and in the school environment must be protected from 
acts of violence committed by teachers, school managers or their friends in the school or other educational institutions".

Law No. 35 of 2014 hints at the importance of the Regency/City government in Indonesia to become a Child-Friendly City. Child-Friendly City (KLA) is a regency / city that has a development system based on children's rights through the integration of commitments and resources of the government, community and business world, which is planned thoroughly and sustainably in policy. The definition of Child-Friendly City above confirms that the active role of all elements is needed to realize a Child-Friendly City. This can be interpreted in a program or activity that can guarantee the fulfillment of children's rights and protection, including the right to enjoy an education free from discrimination, as well as the creation of a more professional child learning environment.

Child-Friendly Schools can be one of the alternative ways to realize a more established and resilient generation of nations in all fields. Related to Child-Friendly Schools in Indonesia requires a profile of educational institutions that can be used as an example as a good child-friendly education management system. Several previous studies have been conducted on Child-Friendly Schools, one of which was conducted by Thapa and Higgins [1] under the title "A Review of School Climate Research" in the journal Review of Educational Research, stating that Child-Friendly Schools are one solution in the protection of children's rights. In his research also stated that there are several indicators that must be met in the application of Child-Friendly Schools, namely: 1) the availability of curriculum documents, 2) child-based education planning, 3) the learning process, and 4) assessment of learning outcomes that refers to the rights of children.

Furthermore, research conducted by Wuri Wuryandani and friends [2], with the research title "Implementation of Fulfillment of Children's Rights Through Child-Friendly Schools" Journal Civics: Media Of Citizenship Studies (Vol. 15 No. 1 Of 2018), explained that Child-Friendly Schools can be used as an alternative to avoid saturation in the learning process. In addition, in the application of child-friendly schools can be implemented through the learning process, ranging from learning planning, implementation of learning and even to the assessment of learning. The results of the study are almost the same as the above research also conducted by Nuri Rohmawati and Endang Hangestiningsih [3], Proceeding Seminar of National Primary School Teacher Education, (April 27, 2019 Yogyakarta), stated that through child-friendly school programs, students are positioned as the subject so that the education process can be realized with safe, clean, healthy conditions, guaranteed fulfillment of children's rights and protection from violence. Students are given the freedom to express their opinions in various areas of knowledge of interest without pressure, discrimination or violence from others.

Based on some previous research above, researchers then saw that this Child-Friendly School system needs to continue to be developed. One example that has now started to implement Child-Friendly Schools is the city of Depok. Depok city is famous for its achievements as a child-friendly city in Indonesia from 2017 to 2019. In July 2019, Depok city was still able to maintain its award as a child-friendly city. This can never be separated from good city management and care for children's education.

In the plenary session of the Depok City Parliament on December 20, 2013 stipulated the Regional Regulation of Child-Friendly City, which then produced Regional Regulation No. 15 of 2013, Depok city government, in his speech explained that there are five clusters of children's rights, namely: (1) civil rights and freedoms, (2) family environment and alternative care, (3) basic health and welfare, (4) education, utilization of free time, and cultural activities, and (5) special protections. This cluster indicates that ChildFriendly Schools are in fourth place in the fulfillment of Child-Friendly Cities.

In Depok Regulation No. 15 of 2013, it is quite clear and detailed to explain about how education and child protection should be. With the Depok Regulation, it can be known that the city of Depok can be said to be one of the cities that cares about children's rights, either covering educational rights or other rights. In addition, Depok city since 2017 has been able to realize one superior program for children's education, namely Child-Friendly Schools. Currently, there are at least 354 educational institutions that declare themselves as Child-Friendly Schools. Child-Friendly Schools are classified as one of the social movements involving many elements, both the city government and surrounding resources. This is none other than to provide the handling of cases of children, especially children facing the law, exploitation, mishandling, neglect, violence.

In addition, referring to Government Regulation No. 19 of 2005 concerning National Standards of Education explains that there are 8 National Standards of Education, namely: 1) content standards, 2) process standards, 3) graduate competency standards, 4) standards of Teacher's and education personnel, 5) standards of facilities and infrastructure, 6) management standards, 7) financing standards, 8) educational assessment standards. Meanwhile, the Office of Women Empowerment and Child Protection and Family Planning of West Java Provincial Government in detail explained about the 8 standards. The details are described as follows: 
Table-1: Details of 8 National Education standards Based on The Office of Women's Empowerment, Child Protection and Family Planning Provincial Government of West Java

\begin{tabular}{|l|l|l|}
\hline No & Standard & Description \\
\hline 1 & Content Standard & $\begin{array}{l}\text { The legal basis lists the Child Protection Law, Learning expenses, education unit } \\
\text { level curriculum, educational calendar, listing the implementation of Child-Friendly } \\
\text { Schools }\end{array}$ \\
\hline 2 & Process Standard & $\begin{array}{l}\text { Protecting students with compassion, respect for each other's rights, fun learning } \\
\text { process and others }\end{array}$ \\
\hline 3 & $\begin{array}{l}\text { Graduate Competency } \\
\text { Standard }\end{array}$ & $\begin{array}{l}\text { Have an anti-violence attitude, have a high tolerance attitude, have a tolerance } \\
\text { attitude care for the environment, have a loyal attitude of friends, and have a proud } \\
\text { attitude towards the school and alma mater. }\end{array}$ \\
\hline 4 & $\begin{array}{l}\text { standards of Teachers } \\
\text { and education personnel }\end{array}$ & $\begin{array}{l}\text { teachers must have educational qualifications in accordance with the subjects, } \\
\text { teachers are able to implement child-friendly schools that are nonviolent }\end{array}$ \\
\hline 5 & $\begin{array}{l}\text { standards of facilities } \\
\text { and infrastructure }\end{array}$ & $\begin{array}{l}\text { Minimum requirements on facilities include: furniture, educational equipment, } \\
\text { educational media, books and other learning resources. } \\
\text { Minimum requirements on infrastructure include: classrooms, principal rooms, } \\
\text { teacher rooms, administrative rooms, library and laboratory rooms, worship rooms } \\
\text { and others. }\end{array}$ \\
\hline 6 & management standards & $\begin{array}{l}\text { The rules are displayed so that children can read, child sanctions must be agreed } \\
\text { between teachers, children, parents and others }\end{array}$ \\
\hline 7 & financing standards & $\begin{array}{l}\text { The cost of providing facilities and infrastructure, development of human resources } \\
\text { and fixed capital, requirements for personal costs of students, minimum } \\
\text { requirements for operational costs, and others. (students are not involved in } \\
\text { financial matters related to parental obligations) }\end{array}$ \\
\hline 8 & $\begin{array}{l}\text { educational assessment } \\
\text { standards }\end{array}$ & $\begin{array}{l}\text { education assessment standard is a national standard of educational assessment on } \\
\text { the mechanisms of procedures and research instruments of student learning } \\
\text { outcomes }\end{array}$ \\
\hline
\end{tabular}

In The Islamic view, Child-Friendly Education is also one of the concerns to realize children's education. In the Islamic education system, children are very important, because it is a mandate that must be maintained in order to be able to become the next generation. In Islam, children also have the rights demanded of parents. Among the rights of the child from the parents are: First, the right to obtain affection and attention. Second, the right to guidance. Third, the right to speak and be heard. Thus, the role of parents is very important for the success of a child's education.

Islam has actually implemented the practice of Child-Friendly Schools since the time of the Prophet Muhammad SAW. He has taught about the pattern of education to children. In Islam Child-Friendly Schools can be associated with the term Tarbiyatul Aulad Fil Islam. The term Tarbiyatul Aulad Fil Islam has the meaning of children's education in Islam. Children are creations of Allah SWT who have special rights. Among the most needed rights for children is the right in terms of education. Education will make children able to become the next generation with dignity.

Child-Friendly Schools in the perspective of Islamic education almost the same as that stated by Abdullah Nashih Ulwan which is contained in one of his works entitled Tarbiyatul Al-Aulad Fil Islam. He explained clearly that education is not only functioning to educate someone, but also one of the efforts to build human awareness in order to have a consciousness of faith. While the concept of education offered is to give freedom to students to choose good and right things and then make their own decisions

In The Islamic View, the concept of education is not only aimed at eliminating ignorance but a process of changing the behavior of individuals and communities into individuals who have noble ethic. Hasan Baharun [4] explained that the concept of Islamic education is one of the efforts to establish a Muslim personality, or a change in attitudes and behaviors in accordance with the instructions of Islamic teachings. In addition, Child-Friendly Schools implemented in Islamic educational institutions tend to only concern the curriculum patterns applied. In fact, much more important is how to form patterns of children's behavior by providing good examples in daily behavior. Sugeng Rugiyanto [5] mentioned that there are at least three types of education that must be given to children, namely, faith education, moral education and social education.

Local regulation No. 15 of 2013 Depok city there are still shortcomings regarding the explanation of indicators in the application of Child-Friendly Schools. Child-Friendly Schools are also classified as one of the indicators in the implementation of Child-Friendly Cities. This is one of the reasons for choosing Depok city in this study. In addition, according to previous research, the Child-Friendly School Program is capable of producing students who are not only intellectually intelligent, but have spiritual intelligence. It is 
important for research to confirm previous findings and offer new concepts or theories to further researchers.

Another reason that also underlies this research is that Depok city is one of the cities that implement the Child-Friendly City system in Indonesia. Even childfriendly school in Depok have begun to be applied in various schools and madrasahs. So Depok is right to be a place of research on child-friendly schools. One example of institutions implementing Child-Friendly Schools is Madrasah Ibtidaiyah An Nizhomiyah and Madrasah Tsanawiyah Depok. The two madrasahs are classified as the only school institutions under the auspices of the Ministry of Religious Affairs that adopt the Child-Friendly School Program in Depok City.

On the other hand, researcher wanted to see the concept of Child-Friendly Schools based on portraits of Islamic education. So far there is still very little research that reviews from the perspective of Islamic education. The presence of this research wants to prove the conformity between Child-Friendly Schools and the concept of Islamic education. As conveyed by Baharudin and friends [6] in his book entitled Theory of study and Learning confirms that the method of education in the religious frame is one step that can be used as a form of response in facing the challenges of the times because historically education cannot be separated from religion.

\section{THEORETICAL ANALYSIS Management}

Management according to the EnglishIndonesian dictionary comes from the word to manage which means to take care, manage, and carry out managing and treating. . While according to Arabic management is defined as idaarah derived from the word adaara which means to regulate. Management is also defined as the act of gathering people then organizing and managing them to achieve the desired goals and goals efficiently and effectively. Management function consists of planning, organizing, implementing/actuating and Controlling/evaluating.

The objectives to be achieved in the student learning process are the first steps that must be taken by the school institution. This requires professional management, both from existing resources and from the system implemented. Therefore, the management of the learning process is very important, starting from the curriculum planning process, organizing resources, implementing the teaching and learning process, and evaluating the learning process.

\section{Child-Friendly School}

Based on Regulation of the Minister of Women Empowerment and Child Protection No. 8 of 2014 article 1, it is explained that, Child-Friendly Schools are formal, non-formal, and informal education units that are safe, clean and healthy, caring and environmentally cultured, able to guarantee, fulfill, respect the rights of children and protection of children from violence, discrimination, and other wrong treatment and support the participation of children, especially in planning, policy, learning , supervision, and complaint mechanisms related to the fulfillment of rights and protection of children in education.

Child-Friendly Schools (SRA) refers to the Regulation of the Minister of Women Empowerment and Child Protection of the Republic of Indonesia Number 8 of 2014 concerning Child-Friendly School Policies, is a school that meets six indicators developed to measure Child-Friendly School (SRA) achievements. The indicators include: 1) Child-Friendly School Policy, 2) Child-friendly learning process, 3) teachers and education personnel trained in children's rights, 4) child-friendly facilities and infrastructure, 5) child participation, 6) participation of parents, business world and other stakeholders including alumni.

\section{Child-Friendly School Learning Model}

There are many learning models in Indonesia. Among them are CBSA (How to Learn Active Students), PAKEM (Active, Creative, Effective and Fun Learning) and developing into PAIKEM (Active, Innovative, Creative, Effective and Fun Learning). This approach emphasizes more on how students learn independently. Joyful learning is a learning model that can motivate students. This contextual learning model has four main principles. The first is interactional process. This principle emphasizes the active interaction of students with friends, teachers, and the environment. The second is communication process; students communicate their learning experiences with their teachers and friends. The third is reflection process; students recall what they have learned and done. The fourth is exploration process; students directly conduct activities such as Observation, Demonstration, Experiment, and Interview.

\section{Islamic Education}

In the treasures of Islamic education thought, there are many terms used by scholars in providing an understanding of Islamic education. Muhaimin [7] mentioned that Islamic education is covered in at least eight understandings, namely; al-tarbiyah al-diniyah (religious education), ta'lim al-din (religious teaching), al-ta'lim al-diiny (religious teachings), al-ta'lim alIslami (Islamic teachings), tarbiyah al-muslimin (Islamic education), al-tarbiyah fi al-Islam (education in Islam), al-tarbiyah inda al-Muslimin (education among the Muslims), and al-tarbiyah al-Islamiyah (Islamic education). However, education experts usually highlight the term more from the different aspects of tarbiyah and ta'lim .

Islamic education is the process of changing individual behavior in the personal life, society, and the surrounding nature, by means of teaching as a basic 
activity and as a profession among the professions in society. Hasan Baharun [4] explained that Islamic education is the formation of a Muslim personality, or a change in attitudes and behaviors in accordance with the instructions of Islamic teachings. Islamic education is basically an education that aims to form a fully Muslim person (kaffah), developing all human potentials in both physical and spiritual forms.

Islamic education is an activity carried out in a planned and systematic way to develop the potential of students based on Islamic rules. Islamic education is an education that aims to achieve the balance of human personal growth as a whole through its psychological exercises, mind, intelligence, feelings and five senses. The ultimate goal of Islamic education is the establishment of Islamic behavior (akhlak) and surrender (faith) to Allah based on the instructions of Islamic teachings (Qur'an and Hadith).

Child-Friendly School in perspective of Islamic education is almost the same as the opinion expressed by Abdullah Nashih Ulwan which is contained in one of his works entitled Tarbiyatul AlAulad Fil Islam. He explained clearly that education is not only functioning to educate someone, but also one of the efforts to build human awareness in order to have a consciousness of faith. While the concept of education offered is to give freedom to students to choose good and right things by making their own decisions.

\section{RESEARCH METHODOLOGY}

The study is classified into field research, where researcher descend directly into the field to obtain the necessary data. The qualitative research type selected in this study aims to explore in depth the object of research. Qualitative method is research that has limited research purpose but with limitations can be excavated as much data about research objectives as possible. . Meanwhile, according to Ronny Kountur [8] explained that qualitative research type has characteristics that the data obtained is stated in a reasonable state. Data collection techniques use observations, interviews, documentation and some literature in the form of relevant journals and books.

This research has two research object places, namely in Madrasah Ibtidaiyyah An-Nizhomiyyah and Madrasah Tsanawiyah depok city. The selection of these two research places is based on considerations found in the field regarding child-friendly schools. Researcher think that the two objects where the study was able to provide new instument on the application of Child-Friendly Schools. In addition, researcher want to prove that Child-Friendly Schools can provide new space for people to care more about education and child rights protection.

\section{RESEARCH RESULTS}

\section{Child-Friendly School (SRA) in the perspective of Islamic Education}

Education is a way to shape children's behavior in interacting. Islamic education is an educative process that leads to the formation of morals or personality. The basis of Islamic education is identical to the basic teachings of Islam itself. Both come from the same source namely the Qur'an and AsSunnah. Then the basis was developed in the understanding of scholars in the form of ijtihad.

According to Omar Mohammad Al-Toumy AlShaibani the purpose of education in Islam is to realize a change towards good, both in the behavior of individuals and in the lives of people in the surrounding environment. It can be known that education is one of the positive steps that can shape a child's pattern of behavior in the life of society. While the understanding of Child-Friendly Education in Islamic education can be concluded is an education system that cares about children's rights through the foundation of the Qur'an and Hadith. All concepts in upholding children's rights are based on the Qur'an and Hadith. Because the nature of child protection in Islam is the appearance of compassion, which is manifested into the fulfillment of basic rights and the provision of protection from acts of violence and acts of discrimination.

Allah SWT instills feelings of affection towards children through the intermediary of parents. The feeling of affection is manifested in the form of fulfilling the needs of children both physical and spiritual, as well as protecting the child from any acts of violence and discrimination. Parental affection will affect the child's development so that the child has a strong and resilient mentality, and has a passion for success in the future. The Prophet reminded in his hadith:

$$
\text { لَيَسنَ مِنَّا مَنْ لَمْ يَرْحَمْ صَنِغِرَنَا وَيُوَقِّرْ كَبِيرَنَا }
$$

It means: "Excluding us, those who do not love children among us and do not glorify the greater among us." (Hadith History: Abu Dawood and Tirmidhi)

Hadith above shows that compassion in child protection is important in fulfilling basic rights and child protection, because Islam is a religion rahmatan lil alamin. Thus child-friendly education in Islamic Education is an effort made by parents and educators in educating their children by creating an environment of compassion.

Madrasah Tsanawiyah Depok was established to lift the dignity of the community through education. This is based on the realization that education is the most valuable asset for an increasingly quality future life. Madrasah Ibtidaiyyah An-Nizhomiyah is an Islamic Plus Elementary School that has been established since 1995 by KH. Abdussomad with a strong commitment to struggle in building people, 
nations and religions. Madrasah Ibtidaiyyah AnNizhomiyah is continuous innovation of information technology-oriented learning and quran-based so that it is expected that the Islamic generation in its soul is firmly embedded competitive values in answering various global challenges.

Along with the times, the two institutions Madrasah Tsanawiyah Depok city and Madrasah Ibtidaiyyah An-Nizhomiyah support the Child-Friendly City through the implementation of child-friendly school system in organizing its education system. Child-Friendly City is one of the programs of the city government to uphold the rights that should be owned by children. This is in line with that conveyed by Wawang Buang as the head of "Teacher and Education Personnel" section that, "The history of this ChildFriendly School is actually derived from child-friendly city. Child-Friendly School is one of the efforts made in supporting the vision and mission of Child-Friendly City in Depok. Thus, it can be said that the beginning of the concept of Child-Friendly School in Depok city began from the application of Child-Friendly City.

Meanwhile, according to the Head of Child Protection, Ibu Yulia Oktavia explained that "ChildFriendly School Policy comes from cases of violence in schools. In addition to protecting children from violence, child-friendly schools are also to save children, for example from unhealthy foods. The policy of the establishment of child-friendly schools according to him is more to the protection of children in school.

The existence of Child-Friendly School policy is expected to create students who have courage in learning, without pressure. They feel the pleasure in the learning process in school. According to Mr. Muhidin as a member of the Committee at Madrasah Tsanawiyah Depok Institute stated that "child-friendly schools are an excellent program, which will better protect children's rights". This is in line with that conveyed by one of the committee members of Madrasah Ibtidaiyyah Nizhamiyah, Mrs. Nurma that "the Child-Friendly School program is very good, in accordance with the application of character values in children, can provide services and protection to all students"

From the two respondents' opinions above, the author understands, This Child-Friendly School is one of the methods of learning in schools that attaches more importance to the rights of students in the learning process. This is also in line with the results of an interview delivered by one of the students of Madrasah Ibtidaiyyah Nizhomiyah, Fathiya stated that "children's participation occurs when the teacher explains and asks for participation in the form of answering and giving opinions. With full friendliness in teaching, students will feel no pressure in the process of Teaching and Learning Activities. Thus, the subject matter delivered by the teacher will be easier for students to understand.
While in the process of establishing ChildFriendly Schools in educational institutions always refer to the decisions that apply by the region or city. ChildFriendly Schools as implemented in the educational institutions madrasah Ibtidaiyyah An-Nizamiyah and Madrasah Tsanawiyah Depok is one of the local government programs in supporting child-friendly cities. The Ministry of Religious Affairs office in Depok as one of the ministries that also houses educational institutions is also asked to approve the implementation of Child-Friendly Schools. This is quite clear as conveyed by Mrs. Lies in her interview stated that "In the Appointment of Child-Friendly Schools, the Office of the Ministry of Religious Affairs was invited by the local government and requested that there be madrasahs that carry out Child-Friendly Schools, then the ministry of religious affairs appointed two madrasahs namely, Madrasah Ibtidaiyyah AnNizhamiyah representing the elementary school level and Madrasah tsanawiyah Depok representing the junior high school level". This statement is quite clear, the Office of the Ministry of Religious Affairs also has a role in the establishment of Child-Friendly Schools.

Child-Friendly Schools as a learning system that has begun to develop among educational institutions demand to always strive to provide the best for children's rights. In realizing the concept of ChildFriendly School learning, good management is needed, starting from planning, organizing, implementing, and evaluating learning outcomes. In Child-Friendly School planning, there are two components that must be fulfilled, firstly the preparation of curriculum and learning planning, in organizing prepared teachers and education personnel to carry out their duties in realizing child-friendly schools. As for the process of implementing child-friendly schools there are several things needed to support these activities, first, learning methods, secondly, child-friendly Learning Facilities and Infrastructure. The next stage is evaluation. The evaluation stage can be seen from several aspects, including teachers, parenting patterns and the surrounding environment.

Based on child-friendly school guidelines from the Ministry of Women Empowerment and Child Protection of the Republic of Indonesia, there are at least six components that must be met in realizing Child-Friendly Schools, and the six components have been implemented well by Madrasah Ibtidaiyah AnNizhomiyah and Madrasah Tsanawiyah Depok. The six components are:

a. Written commitment in the form of Child-Friendly School policy.

This policy is in accordance with the results of interviews submitted by The Head of Madrasah Tsanawiyah Depok and The Head of Madrasah Ibtidaiyah An Nizhamiyah, that the written policy in the framework of child-friendly schools is the making of a 
decree (SK) child-friendly school team by the Head of the Depok Education Office. The Child-Friendly School Team works by making an action plan in advance. Another written commitment is the existence of a childfriendly school curriculum.

\section{b. Child-friendly learning.}

Implementation of child-friendly learning through teacher services to its students. The service is to give affection, smile and give attention, and others.

c. Teachers and education personnel who are trained in children's rights.

Teachers and education personnel become one of the demands and obligations to know all forms of responsibilities and duties in the implementation of Child-Friendly Schools. Based on the interview conducted by the Education Office that "in preparing child-friendly schools, the first training was held for teachers and education personnel". The aim is to form teachers and education personnel who understand the rights of children so that they can implement ChildFriendly Schools.

\section{d. Child-friendly facilities and infrastructure}

In realizing Child-Friendly Schools, facilities and infrastructure are also very supportive, one of which is to support and facilitate children in the learning process. Examples of child-friendly infrastructure is the availability of a decent room, adequate media creativity of children, the existence of children's playgrounds and others

\section{e. Child participation}

The success of Child-Friendly Schools is when children's participation in school increases. Children as learning subjects are not objects so that children can develop their potential and have the courage to express opinions.

f. Participation of parents, community institutions, business world and alumni

The participation of parents, the community and the surrounding environment also affects the success of Child-Friendly Schools. If the surrounding environment does not support the Child-Friendly School program, it will be difficult to make it happen. Alumni also have a role as a consideration for the community to see the results of Child-Friendly School education.

\section{CONCLUSION}

Based on some of the researcher' analysis, researcher were finally able to provide conclusions in this study. In general, this study concluded that the Child-Friendly School system implemented in madrasah Tsanawiyah Depok and Madrasah Ibtidaiyah An-Nizhomiyah Depok is in accordance with the principles applied in Islamic education. Child-Friendly
Schools are not new in the perspective of Islamic education, since long time ago the Islamic education system has implemented a learning system in the form of Child-Friendly Schools.

In realizing the concept of Child-Friendly School learning, good management is needed, starting from planning, organizing, implementation, and evaluation of learning outcomes. The details are as follows: First, Planning: Planning is necessary to know the direction and objectives to be achieved, which is done in the planning, namely: Curriculum Preparation and Child-Friendly School Learning Planning. The implementation is made to prepare teachers and education personnel who understand the rights of children with their respective duties. Third, Implementation: Implementation of Child-Friendly School learning must at least fulfill several things, namely, learning methods and child-friendly facilities and infrastructure. Lastly, Evaluation: Evaluation is necessary to know the success during the learning process. This process can be known through teachers, parenting patterns and the surrounding environment.

Of all the practices carried out in Madrasah, Child-Friendly Schools are in accordance with the Islamic education system and make Madrasah Ibtidaiyyah An Nizhamiyah and Madrasah Tsanawiyah Depok city become excellent madrasahs because in addition to Child-Friendly Schools in accordance with the concept of Islamic education there is a management of the implementation of child-friendly schools into a certain added value in realizing child-friendly education.

\section{REFERENCES}

1. Thapa, A., Cohen, J., Guffey, S., \& HigginsD'Alessandro, A. (2013). A review of school climate research. Review of educational research, 83(3), 357385.

2. Wuri, W. (2018). Implementation of Fulfillment of Children's Rights through Child-Friendly Schools, Civics Journal, Citizenship Study Media, 15(1).

3. Rohmawati, N., \& Endang, H. (2019). Study of ChildFriendly School Program in Character Building in Elementary School, Yogyakarta: accessed at PGSD National Seminar Proceeding. On April 27, 2019.

4. Baharun, H. (2017). Curriculum Development: Theory and Practice (Concepts, Principles, Models, Approaches and Steps to Develop Islamic Religious Education Curriculum). Yogyakarta: Cantrik Pustaka.

5. Rugiyanto, S. (2011). The Thought of Value Education Abdullah Nashih Ulwan in the Book of Children's Education in Islam. Surakarta: UMS.

6. Baharuddin. (2017). Theory of Learn and Learning. Yogyakarta: Ar-Ruz Media.

7. Muhaimin. (2002). Paradigm of Islamic Education. Bandung: Remaja Rosdakarya.

8. Kountur, R. (2004). Research Method for Thesis and Thesis Writing. Jakarta: PPM. Law No. 23 of 2002 on Child Protection, Jakarta: Visi Media. 